\title{
16 \\ HIKAYAT PRANG SABI: \\ Acehnese Jawi as a Medium of Successful Da'wa
}

\author{
Syukri Rizki \\ Goethe Universität Frankfurt am Main \\ syukririzki@gmail.com
}

\begin{abstract}
Besides serving as a means of entertainment, a hikayat in Aceh plays a salient role when it comes to inculcating the Islamic values to perform jihad. An epic Hikayat Prang Sabi - which is written in Acehnese Jawi - is evident to spur the Acehnese people to struggle against the Dutch invaders during the Aceh War. Numerous studies have been conducted on this hikayat to scrutinize the striking motivation it harbors. Noticeably, the hikayat is proof that Acehnese Jawi became an effective medium in successfully transmitting the $d a^{\prime} w a$ to defend land and soul. However, the orthography, unlike Malay Jawi, now suffers from the lack of attention in terms of its writing system. Therefore, it is imperative to study how the orthography is employed so that it had such sheer readability in communicating the divine message. For this reason, this study attempts to unravel the Jawi writing system employed by the author in writing the hikayat. Content analysis is conducted on the script of the hikayat which is the subject of this study. It is found that the hikayat is written in various Acehnese dialects, which then affect the Jawi spelling. The Acehnese Jawi in the hikayat does share the same spelling in some words with Malay Jawi even though pronounced differently. A plethora of Arabic loanwords maintains their original spellings in Acehnese Jawi while some others are customized to suit the progressive change of local pronunciation and due to the attachment of prefixes and suffixes.
\end{abstract}

Keywords: Hikayat Prang Sabi, Acehnese Jawi, medium of da'wa.

\begin{abstract}
Abstrak: Selain berfungsi sebagai sarana hiburan, seorang hikayat di Aceh memainkan peran penting ketika datang untuk menanamkan nilai-nilai Islam untuk melakukan jihad. Epik Hikayat Prang Sabi - yang ditulis dalam bahasa Jawi Aceh terbukti memacu orang Aceh untuk berjuang melawan penjajah Belanda selama Perang Aceh. Sejumlah penelitian telah dilakukan pada hikayat ini untuk meneliti motivasi yang memukau yang dimilikinya. Terlihat bahwa hikayat adalah bukti bahwa Jawi Aceh menjadi media yang efektif dalam mentransmisikan dakwah untuk mempertahankan tanah dan jiwa. Namun, ortografi, tidak seperti Jawi Melayu, sekarang menderita dari kurangnya perhatian dalam hal sistem penulisan. Karena itu, sangat penting untuk mempelajari bagaimana ortografi digunakan sehingga memiliki keterbacaan belaka dalam mengkomunikasikan pesan ilahi. Untuk alasan ini, penelitian ini mencoba mengungkap sistem penulisan Jawi yang digunakan oleh penulis dalam menulis hikayat. Analisis konten dilakukan pada naskah hikayat yang merupakan subjek penelitian ini. Ditemukan bahwa hikayat ditulis dalam berbagai dialek Aceh, yang kemudian mempengaruhi ejaan Jawi. Jawi Aceh dalam hikayat memang memiliki ejaan yang sama dalam beberapa kata dengan Jawi Melayu meskipun diucapkan berbeda. Sebagian besar kata-kata pinjaman Arab
\end{abstract}


mempertahankan ejaan aslinya dalam bahasa Jawi Aceh, sementara yang lain disesuaikan untuk menyesuaikan dengan perubahan progresif pengucapan lokal dan karena lampiran awalan dan sufiks.

Kata Kunci: Hikayat Prang Sabi, Jawi Aceh, medium dakwah.

\section{A. Introduction}

Hikayat is derived from the Arabic term meaning story. In the land of its origin, hikayat is perceived as a set of sequence of a story that reveals the real information of a fact or the artificial one. The term is also used in other languages like Persian, Urdu, Turkish, and India. Arguably, the term also arrives at the Malay World thanks to the Arab migrants who came with Islam, precisely with The Qur'an which written in Arabic script.

In the Malay world, hikayat denotes a set of history that can transmit values to the readers. It is often written in proses using Jawi. Jawi is a script rooted from Arabic yet, due to its limitation in representing non-Arabic phonemes, modified so it has some additional letters ${ }^{375}$. Surely, this also applies to Malay hikayats, as well as the Acehnese ones. Therefore, in this paper, in order to have a clearer picture, we ought to determine that the term 'Malay Jawi' refers to the Malay language written using Jawi, while 'Acehnese Jawi' to Aceh language written using Jawi.

In Aceh, hikayat receives a special position as it functions as entertainment, education means, and social critique. Understandable is that a writing is written in a certain language because it targets mainly the users of the language. However, it does not invariably function that way. A hikayat written in Malay Jawi, for instance, can also be rendered into other languages for the readers of other languages. Some Malay hikayats which have been available in English and French version are like Sejarah Melayu, Hikayat Hang Tuah, and Hikayat Raja Pasai (Haji Salleh, $2010)^{376 .}$

Commonly recognized that, unlike the publications or masterpieces produced in the West which are obsessed so much on copyright, the majority of Malay hikayats deal with the uncertain status of the authorship. For example, the renowned Hikayat Hang Tuah has so far unclear status about who is the author. Intellectual property at that time did not seriously matter as the intent of the author is to disseminate the message not to boast with his intelligence.

This also applies to the case of Aceh. Although some hikayats have their writers for sure, a plethora of others enjoys a disputable status of authorship. Hikayat Malem Diwa, Hikayat Malem Dagang, Hikayat Pocut Muhammad, and Hikayat Nun Parisi are among those dealing with an unclear status of authorship. Because of this, different versions of a certain title of hikayat happen inevitably. Needless to add, Hikayat Prang Sabi also experience this phase. At the moment, in or outside Aceh, one can find various versions of the hikayat.

Having said that, despite all the disputes, one thing that is close to certainty is that Hikayat Prang Sabi is written by Teungku Chik Muhammad Panté Kulu ${ }^{377}$. There are myriads of studies which have been conducted on the hikayat scrutinizing its role in spurring the Acehnese to remain firm in Aceh war.

To date, hardly can we find any single attempt which initiates to determine a standardized spelling of Acehnese Jawi. To best of my knowledge, each writer still relies on his own method in writing Jawi. Aceh has to internalize Malaysia which is eager to develop Jawi to suit the demand of its people. This concern is very likely boosted by ethnic and religious difference. Meanwhile, in Aceh, Jawi use promotion is scarcely a problem because its Muslim majority, thus encountering

375 Teuku Iskandar. “Aceh as Crucible as Malay-Muslim Literature”. In Mapping the Acehnese Past, edited by R. Michael Feener, Patrick Daly, \& Anthony Reid, 41. (Leiden: KITLV, 2011), 41

${ }^{376}$ Siti Hawa Haji Salleh, Malay Literature of the 19th Century. (Kuala Lumpur: Institut Terjemahan Negara Malaysia, 2010), 76.

377 A.Hasjmy. Apa Sebab Rakyat Aceh Sanggup Berperang Puluhan Tahun Melawan Agressi Belanda. (Jakarta: Penerbit Bulan Bintang, 1977), 19-20 
no opponent reactions like in Malaysia. It is imperative for Acehnese Jawi to clarify its status as a priceless intangible legacy of Aceh civilization

Accordingly, the objective of this study is to figure out the Acehnese writing pattern used by the writer, or re-writer, of Hikayat Prang Sabi. As a disclaimer, this study refrains from proposing a new Acehnese Jawi writing patter, nor does it insist that Acehnese Jawi requires a standardized form immediately. To do so, this study raises the question of how are the Jawi writing pattern in Hikayat Prang Sabi. To answer the question, the theory framework follows, then come methodology, results, discussion. A conclusion kindly closes the paper.

\section{B. Conceptual Framework}

Regarding the attempt to unravel the pattern in Jawi script, there are some relevant previous researches. First, Abdul Hamid (2007) undertook a study on three works of Raja Ali Haji Kelana namely, Gurindam Duabelas, Kitab Bustan Al-Katibin, and Kitab Pengetahuan Bahasa, to figure out the difference in Jawi writing system. In the first work 'Gurindam Duabelas', Raja Ali Haji tends not to add a vocal letter in the last syllables of the words who's the first or second syllable is written with the vocal letter. Besides, the use of Arabic loanwords is also found. In the second work 'Kitab Bustan Al-Katibin', He uses diacritics in the last opened and closed syllable like the system of old Jawi writing. However, there are words who's the last opened and closed syllables written with the vocal letter. In the third work 'Kitab Pengetahuan Bahasa', he uses one dot for $g a$ and three dots for $p a$ instead of one dot like in his Kitab Bustan Al-Katibin. It is concluded that there is no significant difference in the three works of Raja Ali Haji. This is plausible because his works are repeatedly rewritten and published with some customizing while his original works are hard to locate.

Second, Sulaiman, Rashidi, and Seong (2015) performed a study that opens the discussion by elaborating the origin of languages in Malay World. The languages coming from Arab, India, and Persia are surmised to contribute to the Jawi writing system. The author also mentions some native languages in Sumatera and Java before the coming of Islam. In general, the author compares some records to trace the root of Jawi writing system. By doing this, the influence of Arab and Persia is identified to enrich to alphabets used in Jawi. Another influence is the lexicon on the Malay language which collects more than 2000 Arabic words and some words deriving from the Persian language.

Third, Abdul Latif (2014) conducted a research studying the development of Jawi writing system which has been proposed by Kang Kyoung Seok. His theory is based on his analysis on Batu Bersurat Terengganu or BBT (1303 M), Daftar Ejaan Melayu (1983), and Dian magazine. This study is a qualitative descriptive study. The author describes how Kang Kyoung Seouk portrays the phases of Jawi development in a table. Regarding Batu Bersurat Terengganu, Seok assumed that the inscription on the stone was done after the 17th century considering the oddness of the writing system which hardly could be found in the 13th century-the time surmised to be the era of the BBT. Regarding Dian magazine, the usage of alif is emphasized in every syllable ending with consonants. Regarding Ejaan Melayu 1983, almost all consonants are written accompanied by vocals. Kang Kyoung Seok is reported to have divided the Jawi writing system development into three phases, namely 1) the elimination of Arabic attributes, 2) using vocals in opened word endings, and 3) the use almost all vocals for all letters.

Another research was conducted by Abdul Aziz, Wan Sulung, and Alian (2017) in which they approached the Jawi writing system in Jawi writing guideline issued by Dewan Bahasa dan Pustaka Malaysia since 1986 namely, Pedoman Ejaan Jawi yang Disempurnakan (PEJYD) and Pedoman Umum Ejaan Jawi Bahasa Melayu (PUEJMB). By doing so, they classified the Jawi spelling into three categories viz. Arabic originated words, Malay originated words, and English originated words. 


\section{Malay Originated Words}

\begin{tabular}{|l|r|l|}
\hline \multicolumn{1}{|c|}{ Rumi } & Jawi & \multicolumn{1}{c|}{ Explanation } \\
\hline Rasa & J & alif is not placed on the last syllable \\
\hline Rama-rama & راما & alif is used in the last syllable \\
\hline Drama & در اما & alif is used in the last syllable \\
\hline
\end{tabular}

\section{Arabic Borrowed Words}

\begin{tabular}{|c|c|c|}
\hline Rumi & Jawi & Explanation \\
\hline Wudhu' & وضوء & the original form is maintained \\
\hline Sabun & سابون & spelling is modified \\
\hline Memfardukan & ممفرضوكن & $\begin{array}{l}\text { in case of prefix and suffix, necessary vowel letter is } \\
\text { added }\end{array}$ \\
\hline Pikir & فيكير & vowel letter is used to avoid ambiguity \\
\hline Musa & 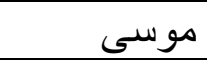 & alif maqshurah is maintained in the original form \\
\hline Memfatwakan & ممفتو اكن & alif maqsurah is modified in case of prefix and suffix \\
\hline Dahsyat & دهثت & sound $\mathrm{t}$ is represented with ta mabshuthah \\
\hline Niat & نية & $\begin{array}{l}\text { original form of ta marbuthath is maintained to } \\
\text { represent sound ' } \mathrm{t} \text { ' }\end{array}$ \\
\hline Fathah & فتحة & $\begin{array}{l}\text { original form of ta marbuthath is maintained to } \\
\text { represent sound ' } h \text { ' }\end{array}$ \\
\hline Hidayat/hidayah & هدية & $\begin{array}{l}\text { both sound 't' and 'h' can be represented with ta } \\
\text { marbuthah }\end{array}$ \\
\hline
\end{tabular}

\section{English Borrowed Words}

\begin{tabular}{|l|l|l|}
\hline Rumi & Jawi & Explanation \\
\hline Bank & بغك & spelled as it is sounded \\
\hline Zink & زينك & spelled as it is sounded \\
\hline
\end{tabular}

All the above-mentioned studies focused on exploring the Jawi writing pattern in Malay Jawi script. Alas, although we can find numerous studies on Acehnese hikayats, the focus was more on the substantial content not on the writing system. So far, to best of my knowledge, there is no study on any single Acehnese hikayat with the purpose to unravel the writing system of Jawi.

So far, hardly can one find any guideline book specialized for Acehnese Jawi writing. Yet, indeed, we still can find a compact, yet so exhaustive, Arabic-Turkish-Malay-Acehnese dictionary. The dictionary is called Nuzhah Al-Ikhwān written by Abdullah bin Ismail Al-Asyi (1930). This dictionary is designed to juxtapose the words on the above-mentioned languages so that the readers may instantly fathom a word in several translations. Below is an instance of the list is as the following:

\begin{tabular}{|c|c|c|c|}
\hline Arabic & Turkish & Malay & Acehnese \\
\hline الْعِلْمُ & بَيْلَمَلَكْ & كَتَهو ان & تَهَزْ \\
\hline الْفَهْرُ & آَكَلْمَنْ & هَرْتَى & تُوُوََْْْ \\
\hline التَّعَلْيْنُ & اوكرنمك & فَغَتَاجَرْ & فُرُوْْنَيْ \\
\hline الْقِرَا اعَةُ & اوقومق & بَجَأُنْنُ & بَجْ \\
\hline
\end{tabular}


Noticeably, from the very upper row to the bottom, we can see the Arabic nouns come first then are translated into Turkish, Malay, and Acehnese. The use of diacritics for Arabic words surely assist readers who possess no sufficient cognitive background to correctly read. It may not, however, apply very effectively to other language translation. In terms of the Acehnese translation in particular, the use of diacritics apparently exacerbates the actual Acehnese pronunciation due to the incommensurability of Acehnese lexicon with the existing limited Arabic letters and diacritics.

In the above-quoted example, one looks closer at the 'Acehnese' row, the inappropriateness of using diacritics is shown very clearly. The word should be pronounced thèe, yet diacritics made it sound tahau; the word تُوَفَّ should be pronounced tupeue, yet diacritics made it tufai; the word فُرُونَنَيْ should be pronounced peureunöe, yet diacritics made it furunai; and lastly, the word بَجْ should be pronounced baca, yet diacritics made it bac.

On the whole, the Acehnese language contains 17 vowels, 17 diphthongs, and 24 consonants (Wildan, 2010) ${ }^{378}$. Intriguing is that how the plenty of language elements could be represented through limited characters of Jawi alphabets. This suggests that before the coming of Rumi brought by European colonizers - either the British or the Dutch, people could manage to read Jawi with the condition of Acehnese Jawi which possess the great number of elements.

\section{Methodology}

This study employs an etymological approach, which is the branch of linguistic knowledge studying the origin and development of words. Every language has a certain system that differs from other languages. Etymology, as put by Malkiev (1962), is perceived as a sub-discipline of lexicology; thus, since viewed as applied science, it is a theoretical and pre-eminently historical study of the lexicon ${ }^{379}$. Acehnese Jawi is now noticed to maintain language features derived from foreign languages with little adjustments to Malay language system, especially in terms of spelling system, sound system, and form of speech. Based on this etymological approach, the Aceh Jawi spelling system can be categorized into three spellings groups, namely, the Arabic originated words, Malay originated words and Acehnese words.

The subject of the study is the script of Hikayat Prang Sabi attached by Aly Hasjmy (1977) in his book 'Apa Sebab Rakyat Aceh Sanggup Berperang Puluhan Tahun Melawan Agressi Belanda', 'Why the Acehnese People were able to fight the Dutch Aggression for Decades'. In the book, the attachment began from page 230 until 351, meaning that the hikayat script has 122 pages.

\section{Hikayat Prang Sabi and Teungku Chik Panté Kulu}

The Dutch colonizers enjoyed severe time in Aceh waging war with Acehnese troops spurred by the provocation of Hikayat Prang Sabi. Prang Sabi itself originally from Arabic Islamic term fi sabilillah, in the way of Allah. Subroto (2015) noted that there was in 1 April 1919 an Acehnese processed in the Dutch hearing due to allegation of killing a Dutch military. The accused stated that in Aceh one would crave a death in a war against the infidels in case he feels bored of the present life.

In this regard, the teachings harbored in Hikayat Prang Sabi did inspire the Acehnese during the colonization to prefer martyrdom. It served as the center of gravity, as termed by (Subroto, 2015, p. 5), which is the crux of all power and movement; the source of moral and physical force; and the source of liberty to do an action.

In essence, the call for Jihad has come from The Qur'an and the Sunnah. Yet, the author of the hikayat noticed that the most effective means to perform the $d a^{\prime} w a$ is through the way already familiar to and recognized by society. Teungku Chik Panté Kulu selected the hikayat form of delivering a message as the finest way by virtue of its uniqueness.

\footnotetext{
378 See appendix

379 Yakov Malkiev, “Etymology and General Linguistics”, Word 18, (1962): 198.
} 
Usually, what is understood as hikayat in Aceh is poetic writing arranged in stanzas (Subroto, 2015, p. 8); other writings which adapt stanzas are pantun, nasihat, and kisah ${ }^{380}$. There are two common genres of hikayat known in Aceh, tambeh and epic hikayats. The former collect hikayats that call for a jihad, while the later collects hikayats which contain a description of the various wars occurring in Aceh, depicting the valor and bravery of the heroes. HPS belongs to the former genre.

In terms of authorship or copyright, rarely can one find, even notice, the authorship of a hikayat. This also happens on Hikayat Prang Sabi where copies owned by some Acehnese concerned over it bear no name of an author too. This implies that authorship did not seriously matter at that time but the substantial content did. Even so, Hasjmy $(1977$, p. 42) contends that the plausibility which is close to certainty that the author Hikayat Prang Sabi is Teungku Chik Muhammad Panté Kulu.

His complete name is Teungku Chik Haji Muhammad Panté Kulu, born in Panté Kulu village, Titeue, Kemalawati, Pidie regency, Aceh, in 1836. He is reported to ever learn Islam through Jawiwritten books; hence, no wonder, his literacy capacity to produce the masterpiece. Such capacity was more deepened as he was educated in Mecca during which he was exposed to a broader spectrum of Arabic poetic literary works (Hasjmy, 1977, p. 50). At that time, Aceh was waging a severe war against the Dutch colonizers. At the very time, Tgk Chik in Mecca was exposed to the movement of Wahabi founder, Muhammad bin Abdul Wahhab, and to the Islamic reformation initiated by Jamaluddin Al-Afghany; this apparently did inculcate some impression in Teungku Chik's soul.

When the Aceh war broke, Teungku Chik heard that Teungku Chik Ditiro, his companion, was mandated an order to lead the war. To respond, he left for Aceh in around 1881. On his way from Jeddah to Penang - the entrepot for Acehnese pilgrims at that time - he wrote the Hikayat Prang Sabi as a present to the Acehnese fighters. Reportedly, his motivation to burn the zest through hikayat was because of the fact that Hassan bin Tsabit did the same when encouraging the Muslims during the epoch of the prophet.

Anthony Reid believed that this hikayat is the most famous epic-poetry among other poetic writings which are read aloud as evening entertainment in meunasahs (communal hall) where people usually assemble ${ }^{381}$. Its popularity even sparked the Dutch attention to banning any acts of reciting, recopying, and distributing the script of the hikayat. The Dutch took forcefully the script of the hikayat from anyone saving it. The enormous influence of this hikayat which inculcated fear among the Dutch is briefly described by an Acehnese artist, Anzib Lamnyong, as he said 382 :

\begin{tabular}{|l|l|}
\hline $\begin{array}{l}\text { Kendati beracun rencong dan pedang, } \\
\text { Hikayat prang sabi lebih berbisa, } \\
\begin{array}{l}\text { Belanda takut lutut bergoyang, } \\
\text { Kisah dilarang menyimpan membaca, }\end{array}\end{array}$ & $\begin{array}{l}\text { Despite the poisonousness of rencong and sword, } \\
\text { Hikayat Prang Sabi is more venomous, } \\
\text { The Dutch fears with trembling knees, } \\
\text { The hikayat is banned from keeping and reading }\end{array}$ \\
$\begin{array}{l}\text { Di zaman Belanda hikayat dilarang, } \\
\text { siapa menyimpan hukuman berganda, } \\
\text { Karena kandungan merangsang perang, } \\
\text { mengobar semangat melawan Belanda }\end{array}$ & $\begin{array}{l}\text { During the Dutch time, the hikayat is forbidden, } \\
\text { Whoever keeps it receives multiple punishments, } \\
\text { For its contents can trigger a war, } \\
\text { Burning the spirit to fight the Dutch }\end{array}$ \\
\hline
\end{tabular}

Seen in such a way, we can understand why keeping the script may cost a severe punishment. Besides, that is why most people at that time tended to memorize the hikayat, resulting in the various version of its copies we see now.

\footnotetext{
380 Subroto. K. Hikayat Perang Sabil: Center of Gravity Jihad Aceh Melawan Kafir Belanda. Syamina, 2015. ${ }^{381}$ A.Hasjmy. Apa Sebab Rakyat Aceh, 55

${ }^{382}$ A.Hasjmy. Apa Sebab Rakyat Aceh, 57
} 
The hikayat consists of four stories namely, (1) Kisah Ainul Mardhiyah, a story about a man meeting a nymph in the paradise as a reward of his martyrdom; (2) Kisah Pasukan Gajah, elephant army story, a story about Abrahah and his troop who made for Mecca targeting the Ka'bah to be demolished; (3) Sa'id Salmy story, a story about an ugly-faced man requesting Prophet Muhammad to get him a wife, then he got involved in a battle against the Jews and died; and (4) Muhammad Amin story, a story a fighter who had to leave his pregnant wife due to the call to Sabil war. As he returned from the war, his spouse with the baby in her womb died. Owing to his strong prayer, God conjured his baby which is a daughter ${ }^{383}$.

A question may come across our mind why actually Hikayat Prang Sabi was successful. Ali Hajmy pointed out three major aspects which made the hikayat 'work' during the desperate time of Aceh war namely linguistic, educational, and $d a^{\prime} w a$ islamiyah aspects. Let us look first at the second and the third.

In terms of education, a hikayat is intended to wake the intelligence up, inculcate good manners, to embed affection towards good deed, and to arouse love towards aesthetics. Suffice it to say that Hikayat Prang Sabi is quite exhaustive to have those values. With regard to da'wa islamiyah, besides instilling the religious Quranic messages e.g. An-Nahl verse 125, Hikayat Prang Sabi served as a successful medium used by the author to conjure the imagination about the rewards that will be given to the martyrs, the readers' internationalization of their shared religious duty to fight.

More stunning is that the linguistic aspect of the hikayat. A literary work is essentially a gift handed by an artist to the audience. Teungku Chik Panté Kulu is noticeably able to articulate his thought through his marvelous words which harbor a fairly high quality of aesthetics. Hikayat Prang Sabi is written in Acehnese language by using Jawi script. Wildan (2010) noted that essentially Acehnese language harbors five functions, namely, as an emblem of Aceh, the symbol of Acehnese identity, a medium of relationship in family, as a means supporting the Acehnese local culture, and as a supporting medium for Acehnese and Indonesian literature ${ }^{384}$. In the main, the language has four major dialects viz. Greater Aceh (spoken in Aceh Besar district), Pidie (spoken in Pidie and Pidie Jaya districts), North Aceh (spoken in North Aceh, East Aceh, and Bireuen districts), and West Aceh (West Aceh, Aceh Jaya, Nagan Raya, and South Aceh districts) ${ }^{385}$. Intriguing is that how Acehnese Jawi, by employing very limited characters, can represent a wide range of Acehnese phonetics viz. seven oral vowels and ten nasal vowels, ten diphthongs, and twenty-four single consonants and twenty-three double consonants (see appendix) ${ }^{386}$.

Based on this, it can be inferred that Teungku Chik Panté Kulu could not avoid the influence of one or more of the Acehnese dialects in writing the hikayat. Born in Pidie, spent last days of his life in Greater Aceh, having two spouses, one from Pidie and the other from Greater Aceh, Teungku Chik might adopt mainly a combination of Acehnese dialects of the two regencies when writing Acehnese Jawi. However, the limitedness of Jawi letters enables Acehnese people of various dialects' speakers to pronounce the verses of the hikayat based on their own dialects.

In this respect, although I come from Lhokseumawe, whereby North Aceh dialect is spoken, my five-year staying in the capital, Banda Aceh, for study and work has broadened my knowledge regarding the variance of other Acehnese dialects, since the capital is the targeted town by Acehnese people coming from almost every nook and corner of Aceh for various purposes. And thus, this experience is quite helpful in assisting me to identify the Acehnese Jawi spellings as intended by the author.

\footnotetext{
${ }^{383}$ A.Hasjmy. Apa Sebab Rakyat Aceh, 51

${ }^{384}$ Wildan. Kaedah Bahasa Aceh. (Banda Aceh: Geuci, 2010), 3 - 4

385 Abdul Gani Asyik. A Contextual Grammar of Acehnese Sentence. (Ann Arbor: University of Michigan, 1987), 3

386 Wildan. Kaedah Bahasa Aceh, 7 - 24
} 


\section{E. (Tentative) Results}

It is found that based on the etymological approach, the Acehnese Jawi employed in Hikayat Prang Sabi can be classified into three categories as the following:

\section{Arabic Borrowed Words}

\section{a. Special Term}

Special terms, words, or phrases that commonly known to have certain spellings in Arabic will not be changed when written in Acehnese Jawi. The instances of this groups are as follows:

\begin{tabular}{cccc}
\hline Acehnese Jawi & Acehnese Rumi & Indonesian/Malay & English \\
\hline نبى & Nabi & Nabi & Prophet \\
الله & Allah & Allah & Allah \\
كتـاب & kitab & kitab & book \\
\hline
\end{tabular}

\section{b. Original spelling and difference pronunciation}

Basically, Arabic borrowed words will receive their original spellings even though they are pronounced differently in Acehnese language. For example, the sound 'l' normally turns to be eliminated and the sound ' $t$ ' will sound as ' $\mathrm{h}$ ' in the Acehnese language.

\begin{tabular}{cccc}
\hline Acehnese Jawi & Acehnese Rumi & Indonesian/Malay & English \\
\hline سبيل & Sabi & Jalan & Way \\
حديث & Hadih & Hadits & $\begin{array}{c}\text { Prophetic } \\
\text { tradition }\end{array}$ \\
\hline
\end{tabular}

\section{c. Arabic spelling modified}

Although most Arabic borrowed words are usually spelled with their original form in Acehnese Jawi, there are still some words which receive necessary modification to suit Acehnese pronunciation.

\begin{tabular}{|c|c|c|c|c|}
\hline Arabic & Acehnese Jawi & Acehnese Rumi & Indonesian/Malay & English \\
\hline واريه & جين & Waréh & Waris & heir \\
\hline جمن علماء علماء & Jen & Ulama & Jin & jin \\
\hline جماء & & Ulama & Scholar \\
\hline
\end{tabular}

\section{d. Vowel letters added to Arabic borrowed words}

Since Acehnese Jawi use no diacritics, mostly, some Arabic borrowed words may receive modification in terms by adding certain vowel letters in one or more of the syllables of the words.

\begin{tabular}{|c|c|c|c|c|}
\hline Arabic & Acehnese Jawi & Acehnese Rumi & Indonesian/Malay & English \\
\hline كافير & kafée & kafir & infidel \\
\hline
\end{tabular}

\section{e. Letter Alif Maqshurah ( $($ ) Modified}

Alif maqshurah which represent the sound ' $a$ ' is written with a usual alif so as to ease the Acehnese readers to identify the intended vowel. 


\begin{tabular}{|c|c|c|c|c|}
\hline Arabic & Acehnese Jawi & Acehnese Rumi & Indonesian/Malay & English \\
\hline L S S S & S & makna & makna & meaning \\
\hline
\end{tabular}

In the main, most Arabic borrowed words maintain original spelling when written in Acehnese Jawi, be they are pronounced exactly as they are written or pronounced differently the way in Acehnese language.

However, the customization on the spelling of the words originated from Arabic may sometimes occur owing to the need for fitting the sound of Acehnese language or the happen unintentionally during the manual re-writing process in the past, resulting in inconsistency in writing the same words.

\section{Malay Borrowed Words}

\section{a. Malay Borrowed Words in Original Spelling}

In most times, Malay borrowed words normally maintain their original spelling when written in Acehnese Jawi, despite the different pronunciation.

\begin{tabular}{|c|c|c|c|}
\hline Acehnese Jawi & Acehnese Rumi & Indonesian/Malay & English \\
\hline دغر & deungöe & dengar & to listen \\
\hline بلى & blöe & beli & to buy \\
\hline كريس & kréh & keris & keris \\
\hline
\end{tabular}

\section{b. Rule of Letter w (sin) and ث (tsa)}

These two letters represent the sound ' $s$ ' and 'ts' respectively. Both sounds are pronounced as ' $h$ ' in Acehnese. In Acehnese Jawi, however, these two letters remain without changing, either the letters attached to Arabic borrowed words or Malay borrowed words.

\begin{tabular}{|c|c|c|c|}
\hline Acehnese Jawi & Acehnese Rumi & Indonesian/Malay & English \\
\hline كريس & kréh & keris & keris \\
\hline لافس & lapéh & lapis & layer \\
\hline هابس & habéh & habis & finished \\
\hline
\end{tabular}

Notwithstanding, in some occasions, the two letters are changed with letter $\bullet$ (ha) to fit the Acehnese language sound.

\begin{tabular}{|c|c|c|c|c|}
\hline Arabic /Malay Jawi & Acehnese Jawi & Acehnese Rumi & Indonesian & English \\
\hline واريه & والوث & waréh & waris & heir \\
\hline هالوس & halôh & Halus & soft \\
\hline
\end{tabular}

c. Rule of letter $\lrcorner\left(\mathrm{ra}^{\prime}\right)$

This letter represents the sound ' $r$ 'in Acehnese and Malay Jawis. When it is placed in the last syllable, it is not pronounced, yet its writing remains, either in case of Arabic or Malay borrowed words.

\begin{tabular}{cccc}
\hline Acehnese Jawi & Acehnese Rumi & Indonesian/Malay & English \\
\hline دغر & deungöe & dengar & to listen \\
دمر & umu & umur & age \\
\hline
\end{tabular}




\section{d. Rule of ta' marbuthah}

Letter ta' marbhuthah of Arabic borrowed words when it comes to Acehnese Jawi spelling and its pronunciation can be categorized into three classes.

1) The original spelling with $t a^{\prime}$ marbuthah is maintained yet it is pronounced as the letter ' $\mathrm{t}$ '

\begin{tabular}{|c|c|c|c|}
\hline Acehnese Jawi & Acehnese Rumi & Indonesian/Malay & English \\
\hline$ح ك ا ي ة$ & hikayat & hikayat & story \\
\hline صحبة & sahabat & sahabat & friend \\
\hline حبة & ayat & ayat & sentence/verse \\
\hline
\end{tabular}

2) Ta' marbuthah in some Arabic borrowed words are changed with ta' mabshuthah to represent the phoneme ' $t$ '.

\begin{tabular}{|c|c|c|c|c|}
\hline Arabic & Acehnese Jawi & Acehnese Rumi & $\begin{array}{c}\text { Indonesian/Mala } \\
\text { y }\end{array}$ & English \\
\hline عبارت & صحبت & ibarat & ibarat & analogy \\
\hline صحابة & sahabat & sahabat & friend \\
\hline
\end{tabular}

3) In some occasions, to represent the sound ' $h$ ', Arabic borrowed words which carry $t a$ ' marbuthah maintain their original spelling in Acehnese Jawi.

\begin{tabular}{|c|c|c|c|}
\hline Acehnese Jawi & Acehnese Rumi & Indonesian/Malay & English \\
\hline عين المرضية & Ainul Mardhiyah & Ainul Mardhiyah & $\begin{array}{c}\text { Ainul } \\
\text { Mardhiyah }\end{array}$ \\
\hline سيد الامة & saidul ummah & penghulu umat & people leader \\
\hline
\end{tabular}

4) In non-Arabic loanwords or real Acehenese words, $t a^{\prime}$ marbuthah is also used, mostly to represent the phoneme ' $\mathrm{t}$ '.

\begin{tabular}{|c|c|c|c|}
\hline Acehnese Jawi & Acehnese Rumi & Indonesian/Malay & English \\
\hline جوة & cut & cilik & little \\
\hline
\end{tabular}

Although $t^{\prime}$ marbuthah is quite relevant to be classified under Arabic loanword explanation, but in this case, it is elaborated separately since it works or is used not only for words derived from Arabic but also Acehnese.

For Arabic loanwords, $t a^{\prime}$ marbuthah works in a certain way. In Arabic itself, $t a^{\prime}$ marbuthah is employed to represent two phonemes, ' $\mathrm{t}$ ' and ' $\mathrm{h}$ ', depending on what condition it is read. In Acehnese Jawi, ta' marbuthah also functions the same way. As examples sketched above, it is pronounced either as ' $t$ ' or ' $h$ ' even if it maintained its original spelling. Even so, on some occasions, the ta' marbuthah in Arabic loanwords which is intended to be pronounced as ' $\mathrm{t}$ ' are changen with $t a$ ' mabsuthah so that there is no ambiguity and confusion for the readers.

Besides, $t a$ ' marbuthah's being pronounced as ' $\mathrm{t}$ ' is also found in some non-Arabic loanwords as the above-mentioned example. 


\section{e. Rule of vowels and diphthongs}

1) Rule of letter 9 (waw)

This letter is used quite often since it represents several vowels and diphthongs.

\begin{tabular}{|c|c|c|c|c|}
\hline vowel/diphthong & Acehnese Jawi & $\begin{array}{c}\text { Acehnese } \\
\text { Rumi }\end{array}$ & $\begin{array}{c}\text { Indonesian/Mala } \\
\text { y }\end{array}$ & English \\
\hline$\hat{o}$ & تروه & trôh & sampai & to arrive \\
\hline u & mudah & mudah & easy \\
\hline$\ddot{0}$ & غونه & ngön & dengan & with \\
\hline e & gو & e & hai & hi \\
\hline ue & guem & harga & price \\
\hline o & po & pemilik & lord \\
\hline
\end{tabular}

\section{2) Rule of letter ي (ya)}

These letters are used interchangeably to represent several vowels and diphthongs.

\begin{tabular}{|c|c|c|c|c|}
\hline vowel/diphthong & Acehnese Jawi & $\begin{array}{l}\text { Acehnese } \\
\text { Rumi }\end{array}$ & $\begin{array}{l}\text { Indonesian/Mala } \\
\mathrm{y}\end{array}$ & English \\
\hline $\mathrm{i}$ & فارى & pari & jin & spirit \\
\hline öe & نغخرى & nanggröe & negeri & country \\
\hline eue & بيت & beuet & baca & to read \\
\hline è & فريه & prèh & tunggu & to wait \\
\hline é & بى & bé & sudut & corner \\
\hline èe & اولى بالغ & ulèe balang & hulubalang & $\begin{array}{c}\text { regional } \\
\text { chief }\end{array}$ \\
\hline $\mathrm{ai}$ & هي & hai & hai & hi \\
\hline
\end{tabular}

\section{f. Determining pronunciation through rhyme}

\begin{tabular}{|c|c|}
\hline Acehnese Jawi & Acehnese Rumi \\
\hline 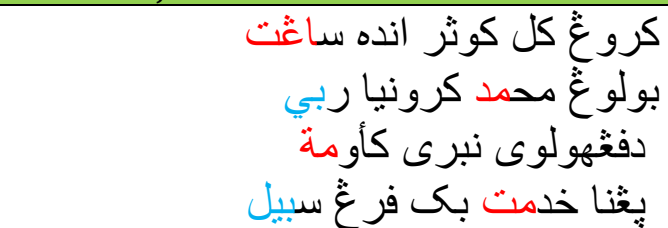 & $\begin{array}{l}\text { Krueng Kalkautsar indah sangat } \\
\text { Bulueng Muhammad karonya Rabbi } \\
\text { Dipangulèe neubri ke umat } \\
\text { Nyang na khidmat bak prang sabi }\end{array}$ \\
\hline Indonesian/Malay & English \\
\hline $\begin{array}{l}\text { Sungai kalkautsar indah sangat } \\
\text { Bagian Muhammad karunia Rabbi } \\
\text { Sang penghulu memberinya ke ummat } \\
\text { Yang berkhidmat dalam perang sabil }\end{array}$ & $\begin{array}{l}\text { Kalkautsar river is very gorgeous } \\
\text { A portion for Muhammad as a gift from God } \\
\text { The master gives it to his people } \\
\text { Who are involved in the Sabil war }\end{array}$ \\
\hline
\end{tabular}

Acehnese poetic writings normally subscribe to the common rules of forming stanzas. Each stanza consists of four verses. A type of stanza is names after the number of syllables each verse of it contains. For axample, a stanza is called harah siplôh type if it consists of ten syllables and is called harah lapan if it consists of eight syllables. Hikayat Prang Sabi seems to combine both types since the integration of haraf lapan and harah siplôh types is frequently found throughout the stanzas. 
Having said that, despite some inconsistencies in the number of syllables when composing stanzas, Hikayat Prang Sabi complies with the common rule of rhyme use. In the instance quoted above, I use color code to emphasize the existence of rhyme. The common rules is that the last syllable of the first verse and the middle syllable of the second verse should rhyme; this is so for the last syllable of the third verse and the middle syllable of the fourth verse. Similarly, the last syllable of the second verse and the last syllable of the fourth verse should also rhyme.

In the above-quoted verse, the syllable Eت (ngat) of the first verse and the syllable s (mad) rhyme. In the same vein, the syllable مة (mat) of the third verse and the syllable (mat) also rhyme; this is the example of the earlier mentioned explanation about how the phoneme ' $\mathrm{t}$ ' can be represented both by $t a^{\prime}$ marbuthah and ta' mabsuthah. Lastly, the last syllable of the second verse بي (bi) and the last syllable of the fourth verse بيل (bi) are also put into the same rhyme.

\section{F. Conclusion and Suggestion}

The act of delivering a message during Aceh war took mainly the oral form. Hikayat Prang Sabi was recited in meunasahs where people usually assembled to encourage them to get involved in the holy war against the Dutch. After knowing that there have numerous publications commenting on how the content of the hikayat in inspiring the Acehnese people, the current paper attempts to investigate how Acehnese Jawi is used to communicate the message successfully.

Considering the ban by the Dutch to copy and distribute the hikayat script, Acehnese people during the Aceh war were more eager to memorize the hikayat or listen to the chanter of it. This apparently resulted in various versions of the copies of the hikayat we can find nowadays. Besides, owing to the manual re-writings of the hikayat's script at that time, inconsistency in Acehnese Jawi spellings is surely inevitable.

It is noticed that each re-writer of hikayat plausibly used his own style when spelling Acehnese words in Acehnese Jawi. Notwithstanding, the script of the hikayat used in this study show some systematic pattern which can be formulated as the further guideline for Acehnese Jawi spellings.

The first and the most noticeable feature of Acehnese Jawi in the hikayat's script is that it employs a plethora of Arabic loanwords. Maintaining the original spelling, some of them are pronounced as they are in Arabic whereas some others are pronounced differently as demanded by Acehenese tongue. Besides, some of their spellings are also modified by changing or adding some letters.

Similarly, in terms of the spelling of Malay loanwords, Acehnese also maintains some and modifies some others.

In general, despite the origin of the words, pronouncing the Acehnese Jawi subscribe to several common rules. Words ending with $w$, and $ث$ normally should be pronounced as ' $h$ '. Words ending with $\lrcorner$ may eliminate their ' $r$ ' sound. Words ending with $\partial$ can be pronounced with ' $t$ ' sound in some occasions and ' $h$ ' in other occasions. However, sometimes the words basically carry " may substitute it with $ت$ when the ' $t$ ' sound is intended.

Regarding the vowels and diphthongs, a single Arabic vowel can represent some vowels when used in Acehnese Jawi. For example, vowel g can represent ô, u, ö, e, ue, and o; and vowel or $\checkmark$ can represent i, öe, eue, è, and é. Further, the certain rhyme used in the hikayat's stanzas does determine how words should be pronounced.

One for sure, Acehnese Jawi was a successful medium to call people for the jihad since its readability transmitted the message of the author to his readers, thereby escalating their bravery to fight a battle defending their land and religion. 


\section{References}

Ahmad, F., \& Hamid, A. (2007). Perkembangan Kaedah Tulisan Jawi: Analisis Beberapa Karya Raja Ali Haji Kelana. Al-Tamaddun, 2, 67-87.

Haji Salleh, S. H. (2010). Malay Literature of the 19th Century. Kuala Lumpur: Institut Terjemahan Negara Malaysia.

Hasjmy, A. (1977). Apa Sebab Rakyat Aceh Sanggup Berperang Puluhan Tahun Melawan Agressi Belanda. Jakarta: Bulan Bintang.

Ismail Al-Asyi, A. (1930). Nuzhatul Ikhwan. Cairo: Mustafa Al-Baby Al-Halaby.

Malkiev, Y. (1962). Etymology and General Linguistics. Word, 18, 198-219.

Subroto, K. (n.d.). K. Subroto.

Sulaiman, S., Rashidi, N. H., \& Seong, T. K. (n.d.). Pengaruh Islam, Arab dan Parsi dalam Inovasi Sistem Tulisan Jawi.

Wildan. (2010). Kaidah Bahasa Aceh. Banda Aceh: Geuci.

Yasran, A., Aziz, A., Muhammad, W., Sulung, W., Melayu, J. B., \& Bahasa, F. (2017). Penaakulan Perkembangan Tulisan Jawi Mutakhir Berdasarkan Etimologi The Reasoning of Current Jawi Script Development Based on Etymology. 4(2), 187-200.

\section{Appendix}

\begin{tabular}{|c|c|c|c|}
\hline Vowel & & & \\
\hline 1 & $\mathrm{a}$ & aduen, adak bak & abang, sekiranyan, pohon \\
\hline 2 & $\mathrm{i}$ & iku, ija, bit & ekor, kain, benar \\
\hline 3 & $\mathrm{e}$ & let, bet, tahe & cabut, angkat, termenung \\
\hline 4 & $\mathrm{eu}$ & eu, aneuk, keudè & lihat, anak, kedai \\
\hline 5 & é & ék, éh, aléh & sanggup, tidur, alif \\
\hline 6 & è & bèk, salèh, mugè & jangan, salih, tengkulah \\
\hline 7 & o & lop, po, pujo & $\begin{array}{l}\text { membalikkan halaman buku, empunya, } \\
\text { puji }\end{array}$ \\
\hline 8 & $\hat{o}$ & ôk, ôn, lôn & rambut, daun, saya \\
\hline 9 & ö & böh, teuöh, gadöh & buang, sebut, hilang \\
\hline 10 & $\mathrm{u}$ & uram, u, bu & pangkal, kelapa, nasi \\
\hline 11 & 'a & 'ap, ‘am, s'ah & suap, awam, bisik \\
\hline 12 & i & 'idah, t'ing, sa'i & idah, bunyi, mengurung diri \\
\hline 13 & 'è & 'èt, la'èh, pa'è & pendek, lemah, tokek \\
\hline 14 & ‘eu & 'eu, ta'eun, & ya, wabah \\
\hline 15 & 'o & 'oh, sy'o, kh'op & ketika, sengau, bau busuk \\
\hline 16 & ‘ö & is'öt, ph'öt & bergeser, bunyi padam api \\
\hline 17 & 'u & ôn 'u, meu'u & belarak, membajak \\
\hline \multicolumn{4}{|l|}{ Diphtong } \\
\hline 1 & ie & ie, iem, lieh & air, diam, jilat \\
\hline 2 & èe & èelia, batèe, bajèe & aulian, batu, baju \\
\hline 3 & eue & pageue, ureueng, leuek & pagar, orang, balam \\
\hline 4 & oe & adoe, toe, taloe & adik, dekat, tali \\
\hline 5 & öe & lagöe & ekspresi untuk hal-hal mengejutkan \\
\hline
\end{tabular}




\begin{tabular}{|c|c|c|c|}
\hline 6 & ue & ue, bue, alue & tersumbat, kera, alur \\
\hline 7 & 'ie & p'iep & hisap \\
\hline 8 & 'èe & ‘èerat & aurat \\
\hline 9 & 'eue & 'eue & merangkak \\
\hline 10 & 'ue & 'uet, c'uet, s'uep & telan, ketatkan, paru \\
\hline 11 & ai & gatai, sai, kai & gatal, sisip, muk \\
\hline 12 & 'ai & meuh'ai & mahal \\
\hline 13 & ei & hei & panggil \\
\hline 14 & oi & boinah & harta benda \\
\hline 15 & ôi & bhôi, cangkôi, do-dôi & kue bolu, cangkul, dodol \\
\hline 16 & öi & lagöina & sangat \\
\hline 17 & ui & bui, phui, ui & babi, ringan, tiri \\
\hline \multicolumn{4}{|l|}{ Consonant } \\
\hline 1 & $\mathrm{p}$ & pajôh, papeuen, kap & \\
\hline 2 & $\mathrm{t}$ & tangké, takue, bateue & tangkai, leher, batal \\
\hline 3 & $\mathrm{c}$ & cah, cabeueng, pucôk & tebas, cabang, pucuk \\
\hline 4 & $\mathrm{k}$ & ka, lakoe, likôt & sudah, suami, belakang \\
\hline 5 & $\mathrm{~b}$ & baroe, bunoe, cabeueng & keamrin, tadi, cabang \\
\hline 6 & $\mathrm{~d}$ & deuh, duroe, gadôh & tampak, duri, lalai \\
\hline 7 & $\mathrm{j}$ & jeumöt, jén, bajèe & rajin, jin, baju \\
\hline 8 & $\mathrm{~g}$ & gabuek, gidöng, lagèe & sibuk, injak, seperti \\
\hline 9 & $\mathrm{f}$ & faké & fakir \\
\hline 10 & $\mathrm{~s}$ & su, sipak, asoe & suara, sepak, isi \\
\hline 11 & sy & syaé, dèsya, kasy'ak & syair, dosa, becek \\
\hline 12 & $\mathrm{~h}$ & h'iem, hôm, jeuheut & teka-teki, entah, jahat \\
\hline 13 & $\mathrm{~m}$ & mat, mantöng, tamöng & pegang, masih, masuk \\
\hline 14 & $\mathrm{n}$ & na, niet, mantöng & ada, niat, masih \\
\hline 15 & ny & nyan, nyoe, siny'ok & itu, ini, hempas \\
\hline 16 & ng & ngeut, ngui, bang'ai & bodoh, pakai, bodoh \\
\hline 17 & $\mathrm{mb}$ & mbôn, mbông, & embun, sombong \\
\hline 18 & nd & kandét, ganda & lipatan, ganda \\
\hline 19 & $\mathrm{nj}$ & panjo, meunjéng, anjông & kapuk, cincin sumur, teras rumah Aceh \\
\hline 20 & ngg & $\begin{array}{l}\text { nggang, panggang, } \\
\text { panggé }\end{array}$ & bangau, panggang, panggil \\
\hline 21 & l & $\begin{array}{l}\text { leumah, langai, } \\
\text { geulunyueng }\end{array}$ & tampak, bajak, telinga \\
\hline 22 & $\mathrm{r}$ & röt, baroe & jalan, kemarin \\
\hline 23 & $\mathrm{w}$ & wa, wie, weueh & peluk, kiri, sedih \\
\hline 24 & $\mathrm{y}$ & yôh, yö & ketika, takut \\
\hline
\end{tabular}

